\title{
In Memoriam - John R. Holsinger
}

\author{
David C. Culver' \\ I Department of Environmental Science, American University, Washington, DC 20016, USA \\ Corresponding author: David C. Culver (dculver@american.edu)
}

Received 1 December 2018 | Accepted 2 December 2018 | Published 12 December 2018

http://zoobank.org/3E89770E-C6C7-4941-9132-5C037A3C5F5E

Citation: Culver DC (2018) In Memoriam - John R. Holsinger. Subterranean Biology 28: 53-66. https://doi.org/ $10.3897 /$ subtbiol.28.32093

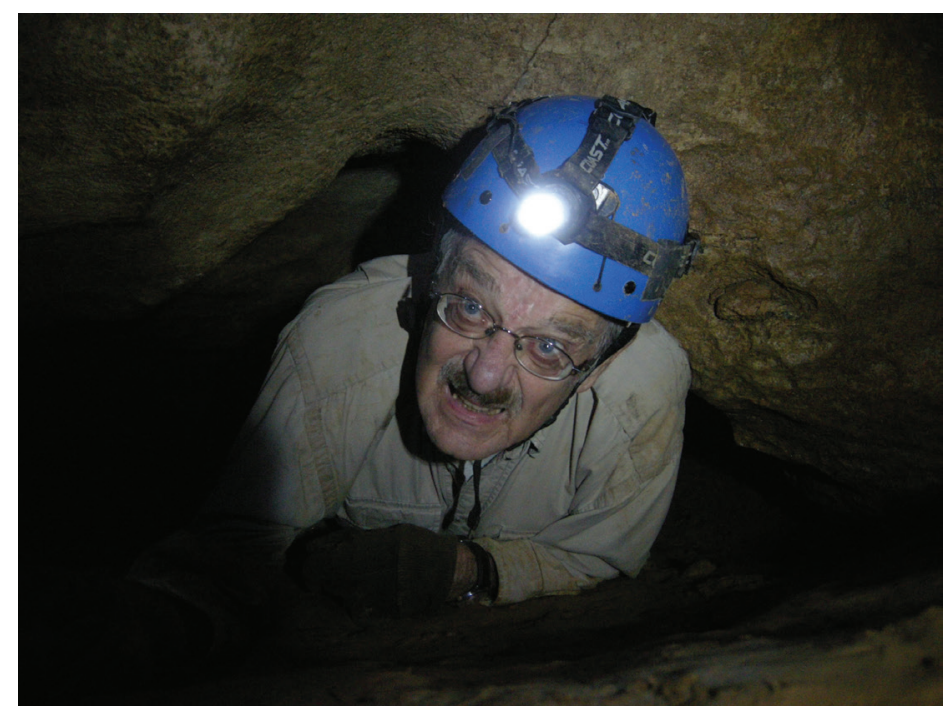

John R. Holsinger, a prominent biospeleologist, both on the national and international scene, died on November 10, 2018. John's caving career spanned nearly 70 years, and his career as a biospeleologist and amphipod systematist spanned more than 50 years. Overall, John wrote more than 135 scientific papers and monographs (listed below). He has left a lasting and significant impact in several areas, not only amphipod systematics, but also subterranean biodiversity, biogeography, and conservation. 
A native of Virginia's Shenandoah Valley, John began going into caves in the 1950's when he was a student at Virginia Polytechnic Institute and State University (now Virginia Tech). After his graduation from VPI in 1955 and a stint in the Army signal corps in Hawaii, he taught high school biology in Fairfax County, Virginia, and started the Biological Survey of Virginia Caves, an NSS supported project. During the late 1950's and early 1960's John was an active vertical caver. Together with his longtime friend and colleague John Cooper, they not only made the first biological collections in many vertical caves in the Virginias, but also helped lead the exploration and survey of these same caves. His speleological career began as an avid caver.

John Holsinger's interest in cave organisms was crystallized by his research for a Master of Science thesis, awarded in 1963 from Madison College (now James Madison University.) Much of his thesis was published in the NSS Bulletin in the form of a checklist of the obligate cave-dwelling organisms found in Virginia caves (1). He developed an interest in the overall diversity of cave life, which continued throughout his scientific career. It is reflected in papers and articles not only about amphipods (see below) but also on bats (2), salamanders $(35,124)$, isopods $(9,10,20,24,44,52,56,86)$ and mites $(4,5)$. He pioneered the idea that overall biological surveys of cave faunas were important, and co-authored annotated lists for Georgia (17), Pennsylvania (31), east Tennessee (67), West Virginia (32), and two monograph length updates of the Virginia cave fauna $(67,133)$, first in 1988 and again in 2013. And he encouraged others to produce lists as well. This seemingly simple lists, often underappreciated, made it possible, in later years, for John and others to make generalizations and maps of subterranean biodiversity hotspots.

After extensive caving in the Virginias during the late 1950's and early 1960's, and with growing interest in subterranean biodiversity, John returned to graduate school at the University of Kentucky, where he obtained his Ph.D. in 1967 under the direction of Thomas C. Barr, a prominent biospeleologist. John's dissertation was on the taxonomy of a group of subterranean amphipods in the genus Stygonectes $(7,8)$ which he eventually classified in the genus Stygobromus. The genus now has about 140 described species, the vast majority of which were described by John $(12,28,38,40,60,65,96,121,123,127,134$, 135). John described hundreds of species, not only in the genus Stygobromus, but in all of the other 8 amphipod genera that occur in North American caves, including the speciose genus Crangonyx $(98,103)$. John documented that Stygobromus, all of which are eyeless, occurred in a variety of subterranean habitats, not just caves. These included deep interstitial habitats, the hyporheic of streams, epikarst, and the hypotelminorheic. While European biospeleologists were well acquainted with non-cave subterranean habitats, Americans were not, and John brought this extra dimension to North American studies. As the years went on, his interest in subterranean amphipods became global, and he described dozens of new species from throughout the world. These included species of Crangonyx and Stygobromus from outside North America $(42,123,130)$, and the cave and interstitial species in the families Bogidiellidae $(89,90,91,108,111,113)$ and Hadziidae $(27,53,57,61$, $74,78,79,87,97,99,100,102,105)$. His enthusiasm for the morphology of cave amphipods was boundless. Anyone who was fortunate enough to hear him give a presentation on subterranean amphipods was treated to an enthusiastic and interesting talk, even if John 
had already described many similar species. In lusiess skilled hands, his talks would have become soporific.

His studies of subterranean amphipods on a global basis led John in two new directions. One was a study of the biogeography of subterranean amphipods and the likely scenarios of colonization and dispersal $(55,66,70,75,88,104,129)$ and he introduced the two-step model of colonization of freshwater subterranean habitats from marine habitats (92). John always remained flexible with respect to the various schools of biogeography and systematics, using and testing components of each (76). His work on biogeography of subterranean amphipods is among the most cited of his publications, with several papers being cited more than 100 times $(55,66)$.

The second direction his studies of subterranean amphipods on a global level was a strong commitment to international cooperation and collaboration. He started attending meeting outside the U.S. in the 1970's at a time well before globalization and well before a time when international cooperation was the norm. This is all the more remarkable for someone who grew up in a small town in the southern United States. The first international meeting John attended was "International Colloquium on Gammarus and Niphargus" in Schlitz, Germany in 1975. It was at this meeting that he forged friendships and collaborations with a multitude of biospeleogists from throughout the world, including Magniez (France), Ruffo (Italy), Siderov (Russia), Skalski (Poland) Sket (Slovenia), and Straškraba (Czech Republic). In 1978, together with Arthur Buikema, he organized an "International Symposium on Groundwater Ecology" in Blacksburg, Virginia, and provided Americans with their first opportunity to meet their international colleagues. John was a mainstay of the International Society for Subterranean Biology, attending most of the biennial meetings up to the meeting in Košice, Slovakia in 2012. He always treated his colleagues, not just with dignity and respect, but with enthusiasm and genuine appreciation of their work

Although John never thought of himself as an isopod taxonomist, he authored or co-authored eight papers on isopods and described several new species $(9,10,20,24,44,52,56,86)$. He also made significant contributions to our understanding of the ecology and natural history of subterranean organisms, especially with respect to amphipods $(6,14,33,44,49,80,122)$.

John was a lifelong teacher. A high school biology and earth science teacher in the early days, he went on to be a professor at East Tennessee State University and Old Dominion University, where he spent most of his professorial career. He mentored a number of graduate students both at the Masters and PhD levels, including Ph.D. students Jill Yager, discoverer of the Remipedes, a previously unknown class of Crustacea; Lynn Ferguson, expert on cave adapted diplurans of North America; Jun Zhang, expert on Crangonyx amphipods; Stefan Koenneman, expert on Bogidiellid and Crangonyctid amphipods; Tom Sawicki, expert on Hadzioidea amphipods; and Julian Lewis, the leading expert on freshwater isopods of North America. John enlightened hundreds of Old Dominion University students over the decades through his unique course on Cave Biology, leading weekend long field trips to caves in Virginia and West Virginia to see some of the fascinating places and creatures covered in his lectures. He was a teacher to almost everyone he met, and had a singular ability to impart knowledge without condescension or arrogance. All of us learned a lot from him. 
I am not sure if John had one favorite cave, but a good candidate would be Unthanks Cave in Lee County, an $12 \mathrm{~km}$ long cave with an abundant and diverse fauna. John was instrumental in persuading The Nature Conservancy to purchase the land above the entrance. The Virginia state Natural Heritage Program and The Nature Conservancy continue working together to protect all of the land overlying or draining to the cave. John Holsinger's conservation efforts extended far beyond protecting a handful of his favorite caves. John was part of a group of pioneers who saw a role for the state in the recognition and protection of cave and karst resources. Starting with the Commission on Virginia Caves and culminating with the Virginia Cave Board, John served thirty years as a governor appointed citizen volunteer working to protect the state's karst. Notable achievements of these boards included the passage of the Virginia Cave Protection Act in 1979 , regulation of scientific studies to limit impacts to caves, recognition of the paleontological, archaeological, and associated cultural significance of caves, and direct actions to conserve and restore threatened and degraded cave systems. John's efforts led to the 1982 listing of the Madison Cave isopod (Antrolana lira) as threatened under the endangered species act as part of a successful attempt to prevent discharge of chlorinated water to a sinkhole overlying the species' type locality. In the 1980s John led the Cave Board campaign to restore and protect Lee County's Thompson Cedar Cave, which he discovered had been contaminated by leachate flowing from massive sawdust piles adjacent to and overlying the cave. The impact was so severe that almost all life in the cave had been extinguished, resulting in the Endangered Species listing in 1992 of the Lee County Cave isopod (Lirceus usdagalun). The protection and resources afforded these two species have resulted in increased knowledge and long term protections not only of these animals, but the caves and groundwater in which they live. Early on, John recognized the threats human activity posed to caves and cave fauna (6) and actively sought their protection, even when he was a very lonely voice calling for protection. It is not an overstatement that his actions have brought species like Lirceus usdagalun back from the brink of extinction.

John still somehow managed to make time for Linda, his wife of four decades, and their extended family, who together with us mourn his passing and celebrate his life. Linda was his mainstay and devoted caregiver in his later years. In honor of John's work toward our understanding of caves, cave biology, conservation and taxonomy, the Virginia Natural Heritage Program established the John R. Holsinger Cave Conservation Fund. Those wishing to contribute should contact the Virginia Department of Conservation and Recreation Division of Natural Heritage at 804-786-7951. Checks can be sent clo John R. Holsinger Cave Conservation Fund, 600 East Main Street, 16 ${ }^{\text {th }}$ floor, Richmond, Virginia, 23219.

In all his activities, John Holsinger was incredibly generous in sharing both time and credit. He always welcomed new people to caving and cave biology. He could also be irascible, and it is fair to say he did not suffer fools gladly. Setting an example which we all would do well to follow, John took the time to carefully document and publish nearly everything he did, leaving a lasting contribution to both the caving and broader scientific communities. In a real sense, he devoted his life to speleology, which will be much diminished by his passing.

I wish to thank Chris Hobson and Wil Orndorff of the Virginia Department of Conservation and Recreation for help in tracking down details of John's remarkable life. 


\section{List of publications by John R. Holsinger}

1. Holsinger JR (1963) Annotated checklist of the macroscopic troglobites of Virginia, with notes on their geographic distribution. Bulletin of the National Speleological Society 24: 23-36.

2. Holsinger JR (1964) The gray myotis (Myotis grisescens) in Virginia. Journal of Mammalogy 45: 151-152.

3. Holsinger (1964) The biology of Virginia caves. In: Douglas HH (Ed.) Caves of Virginia, Virginia Cave Survey: 57-74.

4. Holsinger JR (1965) Redescriptions of two poorly known species of cavernicolous rhagidiid mites (Acarina: Trombidiformes) from Virginia and Kentucky. Acarologia 7: 654-662.

5. Holsinger JR (1965) Free living mites (Acarina) in caves of the eastern United States. Bulletin of the National Speleological Society 27: 47-64.

6. Holsinger JR (1966) A preliminary study on the effects of organic pollution of Banners Corner Cave, Virginia. International Journal of Speleology 2: 75-89. https://doi. org/10.5038/1827-806X.2.1.6

7. Holsinger JR (1966) Subterranean amphipods of the genus Stygonectes (Gammaridae) from Texas. American Midland Naturalist 76: 100-124. https://doi. org/10.2307/2423237

8. Holsinger JR (1967) Systematics, speciation, and distribution of the subterranean amphipod genus Stygonectes (Gammaridae). Bulletin of the United States National Museum 259: 1-176. https://doi.org/10.5479/si.03629236.259.1

9. Holsinger JR (1967) New data on the range of the troglobitic trichoniscid isopod Caucasonethes henroti. Journal of the Tennessee Academy of Science 42: 15.

10. Steeves HR III, Holsinger JR (1968) Biology of three new species of troglobitic asellids from Tennessee. American Midland Naturalist 76: 100-124. https://doi. org/10.2307/2423604

11. Holsinger JR, Peck SB (1968) A new genus and species of subterranean amphipod (Gammaridae) from Puerto Rico, with notes on its ecology, evolution, and relationship to other Caribbean amphipods. Crustaceana 15: 249-262. https://doi. org/10.1163/156854068X00368

12. Holsinger JR (1969) The systematics of the North American subterranean amphipod genus Apocrangonyx (Gammaridae), with remarks on ecology and zoogeography. American Midland Naturalist 81: 1-28. https://doi.org/10.2307/2423647

13. Holsinger JR (1969) Biogeography of the freshwater amphipod crustaceans (Gammaridae) of the central and southern Appalachians. In: Holt PC (Ed.) The Distributional History of the Biota of the Southern Appalachians, Part I: Invertebrates. Research. Division Monograph 1 of Virginia Polytechnic Institute \& State University, 19-50.

14. Culver DC, Holsinger JR (1969) Preliminary observation on sex ratios in the subterranean amphipod genus Stygonectes (Gammaridae). American Midland Naturalist 82: 631-633. https://doi.org/10.2307/2423810

15. Holsinger JR, Culver DC (1970) Morphological variation in Gammarus minus Say (Amphipoda, Gammaridae) with emphasis on subterranean forms. Postilla 146: 1-24. 
16. Holsinger JR, Minckley WL (1971) A new genus and two new species of subterranean amphipod crustaceans (Gammaridae) from northern Mexico. Proceedings of the Biological Society of Washington 83: 425-444.

17. Holsinger JR, Peck SB (1971) The invertebrate cave fauna of Georgia. Bulletin of the National Speleological Society 33: 23-44.

18. Barr Jr TC, Holsinger JR (1971) Biogeography of troglobites. Bulletin of the National Speleological Society 33: 115-118.

19. Holsinger JR (1971) A new species of the subterranean amphipod genus Allocrangonyx (Gammaridae), with a redescription of the genus and remarks on its zoogeography. International Journal of Speleology 3: 317-331. https://doi.org/10.5038/1827806X.3.3.11

20. Holsinger JR and Steeves HR III (1971) A new species of subterranean isopod crustacean (Asellidae) from the central Appalachians, with remarks on the distribution of other isopods of the region. Proceedings of the Biological Society of Washington 84: 189-200.

21. Holsinger JR (1972) The freshwater amphipod crustaceans (Gammaridae) of North American. Biota of Freshwater Ecosystems, Identification Manual 5. U.S. Environmental Protection Agency, Washington, DC, 89 pp.

22. Holsinger JR (1973) Two new species of the subterranean amphipod genus Mexiweckelia (Gammaridae) from Mexico and Texas, with notes on the origin and distribution of the genus. Association of Mexican Cave Studies Bulletin 5: 1-12.

23. Holsinger JR, Straskraba M (1973) A new genus and two new species of subterranean amphipod crustaceans (Gammaridae) from South Africa. Annales de Spéléologie 28: 69-79.

24. Holsinger JR, Bowman TE (1974) A new troglobitic isopod of the genus Lirceus (Asellidae) from southwestern Virginia, with notes on its ecology and additional cave records for the genus in the Appalachians. International Journal of Speleology 5: 261-271. https://doi.org/10.5038/1827-806X.5.3.5

25. Culver DC, Holsinger JR, Baroody RA (1974) Toward a predictive cave biogeography: The Greenbrier Valley as a case study. Evolution 27: 689-695. https://doi. org/10.1111/j.1558-5646.1973.tb00716.x

26. Holsinger JR (1974) Comments on the newly proposed gammaridean families Crangonycidae and Melitidae. Crustaceana 26: 316-318. https://doi. org/10.1163/156854074X00721

27. Holsinger JR (1974) A new cavernicolous amphipod crustacean of the genus Hadzia (Gammaridae) from Jamaica, with notes on the distribution and taxonomic status of the genus. Annales de Spéléologie 29: 647-655.

28. Holsinger JR (1974) Systematics of the subterranean amphipod genus Stygobromus (Gammaridae), Part I: Species of the western United States. Smithsonian Contributions to Zoology 160: 1-63. https://doi.org/10.5479/si.00810282.160

29. Holsinger JR (1975). Descriptions of Virginia caves. Virginia Division of Mineral Resources Bulletin 85: 1-450. 
30. Estes JA, Holsinger JR (1976) A second troglobitic species of the genus Lirceus (Isopoda, Asellidae) from southwestern Virginia. Proceedings Biological Society Washington 89: 481-490.

31. Holsinger JR (1976) The cave fauna of Pennsylvania. In: White WB (Ed.) Geology and Biology of Pennsylvania caves. Pennsylvania Geological Survey ( $4^{\text {th }}$ series), General Geology Report 66. Harrisburg, 72-87.

32. Holsinger JR, Baroody RA, Culver DC (1976) The invertebrate cave fauna of West Virginia. West Virginia Speleological Survey Bulletin 7: 1-82.

33. Holsinger JR, Dickson GW (1977) Burrowing as a means of survival in the troglobitic amphipod crustacean Crangonyx antennatus Packard (Crangonyctidae). Hydrobiologia 54: 196-199. https://doi.org/10.1007/BF00014284

34. Beckett DC, Lewis PA, Holsinger JR (1977) Report of an amphipod species new to Ohio: Gammarus minus Say (Amphipoda: Gammaridae). Ohio Journal of Science 77: 242-243.

35. Besharse JC, Holsinger JR (1977) Gyrinophilus subterraneus, a new troglobitic salamander from southern West Virginia. Copeia (1977): 624-634. https://doi. org/10.2307/1443160

36. Holsinger JR (1977) A review of the systematics of the Holarctic amphipod family Crangonyctidae. Crustaceana Supplement 4: 244-281.

37. Holsinger JR (1977) A new genus and two new species of subterranean amphipod crustaceans (Gammaridae s. lat.) from the Yucatan Peninsula in Mexico. Association of Mexican Cave Studies Bulletin 6: 15-25.

38. Holsinger JR (1978) Systematics of the subterranean amphipod genus Stygobromus (Crangonyctidae), Part II: Species of the eastern United States. Smithsonian Contributions to Zoology 266: 1-144. https://doi.org/10.5479/si.00810282.266

39. Dickson GW, Patton, GW, Holsinger JR, Avise J (1979). Genetic variation in cave-dwelling and deep-sea organisms, with emphasis on Crangonyx antennatus (Crustacea: Amphipoda) in Virginia. Brimleyana 2: 119-130.

40. Holsinger JR (1980). Stygobromus canadensis, a new subterranean amphipod crustacean (Crangonyctidae) from Canada, with remarks on Wisconsin refugia. Canadian Journal of Zoology 58: 90-97. https://doi.org/10.1139/z80-034

41. Holsinger JR, Longley G (1980) The subterranean amphipod crustacean fauna of an artesian well in Texas. Smithsonian Contributions to Zoology 308: 1-62. https://doi. org/10.5479/si.00810282.308

42. Holsinger JR, Skalski AW (1980) The taxonomy and systematic status of Crangonyx paxi Schellenberg (Crangonyctidae). Crustaceana Supplement 6: 17-26.

43. Holsinger JR (1981) Stygobromus canadensis, a troglobitic amphipod crustacean from Castleguard Cave, with remarks on the concept of cave glacial refugia. Proceedings of the $8^{\text {th }}$ International Congress of Speleology, Bowling Green, Kentucky 1: 93-95.

44. Collins TL, Holsinger JR (1981) Population ecology of the troglobitic isopod crustacean Antrolana lira Bowman (Cirolanidae). Proceedings of the $8^{\text {th }}$ International Congress Speleology, Bowling Green, Kentucky 1: 129-132. 
45. Hubbard Jr DA, Holsinger JR (1981) Karst development in Rye Cove, Virginia. Proceedings of the $8^{\text {th }}$ International Congress of Speleology, Bowling Green, Kentucky 2: 515-517.

46. Holsinger JR (1981) Amphipoda. In: Hurlbert SH, Rodriguez G, Santos ND (Eds) Aquatic Biota of Tropical South America, Part 1: Arthropoda. San Diego State University, San Diego, 36-40.

47. Bousfield EL, Holsinger JR (1981) A second new subterranean amphipod crustacean of the genus Stygobromus (Crangonyctidae) from Alberta, Canada. Canadian Journal Zoology 59: 1827-1830. https://doi.org/10.1139/z81-250

48. Ward JV Holsinger JR (1981) Distribution and habitat diversity of subterranean amphipods in the Rocky Mountains of Colorado, U.S.A. International Journal of Speleology 11: 63-70. https://doi.org/10.5038/1827-806X.11.1.7

49. Dickson GW, Holsinger JR (1981) Variation among populations of the troglobitic amphipod crustacean Crangonyx antennatus Packard (Crangonyctidae) living in different habitats, III: Population dynamics and stability. International Journal of Speleology 11: 33-48. https://doi.org/10.5038/1827-806X.11.1.5

50. Holsinger JR (1982) A preliminary report on the cave fauna of Burnsville Cove, Virginia. Bulletin of the National Speleological Society 44: 98-101.

51. Holsinger JR (1982) Amphipoda. In: Hurlbert SH, Villalobos-Figueroa A (Eds) Aquatic Biota of Mexico, Central America and the West Indies. San Diego State University publication, San Diego, California, 209-214.

52. Estes JA, Holsinger JR (1982) A comparison of the structure of two populations of the troglobitic isopod crustacean Lirceus usdagalum (Asellidae). Polskie Archiwum Hydrobiologii 29: 453-461.

53. Holsinger JR (1982) Paramexiweckelia, a new genus of subterranean amphipod (Hadziidae) from northern Mexico. International Journal of Speleology 12: 37-44. https://doi. org/10.5038/1827-806X.12.1.4

54. Holsinger JR, Mort JS, Recklies AD (1983) The subterranean crustacean fauna of Castleguard Cave, Columbia ice-fields, Alberta, Canada, and its zoogeographic significance. Arctic and Alpine Research 15: 543-549. https://doi.org/10.2307/1551240

55. Barr Jr TC, Holsinger JR (1985) Speciation in cave faunas. Annual Review of Ecology and Systematics 16: 313-337. https://doi.org/10.1146/annurev.es.16.110185.001525

56. Lewis JJ, Holsinger JR (1985). Caecidotea phreatica, a new phreatobitic isopod crustacean (Asellidae) from southeastern Virginia. Proceedings of the Biological Society of Washington 98: 1004-1011.

57. Holsinger JR, Yager J (1985) A new genus and two new species of subterranean amphipod crustaceans (Hadziidae) from the Bahamas and Turks and Caicos Islands. Bijdragen Dierkunde 55: 283-294.

58. Holsinger JR (1986) Amphipoda: Sebidae. In: Botosaneanu L (Ed.) Stygofauna Mundi. Brill/Backhuys, Leiden, 568-569.

59. Holsinger JR (1986). Holarctic crangonyctid amphipods. In: Botosaneanu L (Ed.) Stygofauna Mundi. Brill/Backhuys, Leiden, 535-549. 
60. Holsinger JR, Shaw DP (1986) A new stygobiont amphipod crustacean (Crangonyctidae, Stygobromus) from glaciated karst on Vancouver Island, Canada. Communications of the $9^{\text {th }}$ International Congress of Speleology, Barcelona 2: 98-101.

61. Holsinger JR, Williams DW, Yager J, Iliffe TM (1986) Zoogeographic implications of Bahadzia, a hadziid amphipod crustacean recently described from anchialine caves in the Bahamas and Turks and Caicos Islands. Stygologia 2: 77-83.

62. Stock JH, Holsinger JR, Sket B, Iliffe TM (1986) Two new species of Pseudoniphargus (Amphipoda), in Bermudian groundwaters. Zoologia Scripta 15: 237-249. https://doi. org/10.1111/j.1463-6409.1986.tb00226.x

63. Holsinger JR (1986) Zoogeographic patterns of North American subterranean amphipod crustaceans. In Gore RH, Heck KL (Eds) Crustacean Biogeography, Crustacean Issues 4. Balkema, Rotterdam, 85-106.

64. Holsinger JR (1987) Redescription of the stygobiont amphipod crustacean Stygobromus pusillus (Crangonyctidae) from the Soviet Union, with comments on taxonomic and zoogeographic relationships. Journal of Crustacean Biology 7: 249-257. https://doi. org/10.2307/1548605

65. Holsinger JR, Shaw DP (1987) Stygobromus quatsinensis, a new subterranean amphipod crustacean (Crangonyctidae) from caves on Vancouver Island, British Columbia, Canada, with remarks on zoogeographic relationships., Canadian Journal of Zoology 65: 2202-2209. https://doi.org/10.1139/z87-334

66. Holsinger JR (1988) Troglobites: The evolution of cave-dwelling organisms. American Scientist 76: 146-153.

67. Holsinger JR, Culver DC (1988) The invertebrate cave fauna of Virginia and a part of eastern Tennessee: Zoogeography and ecology. Brimleyana 14: 1-162.

68. Godfrey RB, Holsinger JR, Carson KA (1988) A comparison of the morphology of calceoli in the freshwater amphipods Crangonyx richmondensis s. lat. (Crangonyctidae) and Gammarus minus (Gammaridae). Crustaceana Supplement 13: 115-121.

69. Bousfield EL, Holsinger JR (1989) A new crangonyctid amphipod crustacean from hypogean fresh waters of Oregon. Canadian Journal of Zoology 67: 963-968. https:// doi.org/10.1139/z89-139

70. Holsinger JR (1989) Preliminary zoogeographic analysis of five groups of crustaceans from anchialine caves in the West Indian region. Proceedings of the $10^{\text {th }}$ International Congress of Speleology, Budapest 1: 25-26.

71. Holsinger JR (1989) Allocrangonyctidae and Pseudocrangonyctidae, two new families of holarctic subterranean amphipod crustaceans (Gammaridea), with comments on their phylogenetic and zoogeographic relationships. Proceeding of the Biological Society of Washington 102: 947-959.

72. Hershler R, Holsinger JR (1990) Zoogeography of North American hydrobiid cavesnails. Stygologia 5: 5-16.

73. Hershler R, Holsinger JR, Hubricht L (1990) Systematics of the North American hydrobiid genus Fontigens. Smithsonian Contributions to Zoology 509: 1-49. https://doi. org/10.5479/si.00810282.509 
74. Holsinger JR (1990) Tuluweckelia cernua, a new genus and species of stygobiont amphipod crustacean (Hadziidae) from anchialine caves on the Yucatan Peninsula. Beaufortia 41: 97-107.

75. Botosaneanu L, Holsinger JR (1991) Some aspects concerning colonization of the subterranean realm - especially of subterranean waters: A response to Rouch \& Danielopol. Stygologia 6: 11-39.

76. Holsinger JR (1991) What can vicariance biogeographic models tell us about the distributional history of subterranean amphipods? Hydrobiologia 223: 43-45. https://doi. org/10.1007/BF00047627

77. Holsinger JR (1992) Sternophysingidae, a new family of subterranean amphipods (Gammaridea, Crangonyctoidea) from South Africa, with description of Sternophysinx calceola, a new species, and comments on phylogenetic and biogeographic relationships. Journal of Crustacean Biology 12: 111-124. https://doi.org/10.2307/1548726

78. Holsinger JR (1992) Two new species of the subterranean amphipod genus Bahadzia (Hadziidae) from the Yucatan Peninsula region of southern Mexico, with an analysis of the phylogeny and biogeography of the genus. Stygologia 7: 85-105.

79. Holsinger JR (1992) Four new species of subterranean amphipod crustaceans (Artesiidae, Hadziidae, Sebidae) from Texas, with comments on their phylogenetic and biogeographic relationships. Texas Memorial Museum Speleological Monographs 3: 1-22.

80. Culver DC, Jones WK, Holsinger JR (1992) Biological and hydrological investigation of the Cedars, Lee County, Virginia, an ecologically significant and threatened karst area. Proceedings of the $1^{\text {st }}$ International Conference on Ground Water Ecology, 281-290.

81. Culver DC, Holsinger JR (1992) How many species of troglobites are there? Bulletin of the National Speleological Society 54: 79-80.

82. Holsinger JR (1993) Biogeographic patterns of North American subterranean amphipods in the genus Stygobromus (Crangonyctidae). Proceedings of the XI International Congress of Speleology, Beijing, China, 118-12.

83. Holsinger JR (1993) Biodiversity of subterranean amphipod crustaceans: global patterns and zoogeographic implications. Journal of Natural History 27: 821-835. https:// doi.org/10.1080/00222939300770501

84. Holsinger JR (1994) Pattern and process in the biogeography of subterranean amphipod crustaceans. Hydrobiologia 287: 131-145. https://doi.org/10.1007/BF00006902

85. Holsinger JR (1994). Subterranean amphipods. In: Juberthie C, Decu V (Eds) Encyclopaedia Biospeologica, Tome I., Société de Biospéologie, Moulis and Bucarest, 147-163.

86. Holsinger JR, Hubbard Jr DA, Bowman TE (1994). Biogeographic and ecological implications of newly discovered populations of the stygobiont isopod crustacean Antrolana lira Bowman (Cirolanidae). Journal of Natural History 28: 1047-1058. https://doi. org/10.1080/00222939400770551

87. Holsinger JR (1996. Paramexiweckelia ruffoi, a new species of subterranean amphipod crustacean (Hadziidae) from south-central Texas, with observations on phylogenetic and biogeographic relationships. Bollettino del Museo Civico di Storia Naturale di Verona 20: 89-103. 
88. Holsinger JR, Carlson KR, Shaw DP (1997) Biogeographic significance of recently discovered amphipod crustaceans (Stygobromus) in caves of southeastern Alaska. Proceedings of the $12^{\text {th }}$ International Congress of Speleology 3: 347-349.

89. Koenemann S, Holsinger JR (1999) Megabogidiella azul n. gen, n. sp., a cavernicolous amphipod crustacean of the family Bogidiellidae from Brazil, with remarks on its biogeographic and phylogenetic relationships. Proceedings of the Biological Society of Washington 112: 572-580.

90. Koenemann S, Holsinger JR (1999) Phylogenetic analysis of the amphipod crustacean family Bogidiellidae, s. lat., and revision of taxa above the species level. Crustaceana 72: 781-816. https://doi.org/10.1163/156854099503960

91. Koenemann S, Holsinger JR (2000) Revision of the subterranean amphipod genus Spelaeogammarus (Bogidiellidae) from Brazil, including descriptions of three new species and considerations of their phylogeny and biogeogaphy. Proceedings of the Biological Society of Washington 113: 104-123.

92. Holsinger JR (2000) Ecological derivation, colonization, and speciation. In: Wilkens H, Culver DC, Humphreys WF (Eds) Subterranean Ecosystems. Elsevier, Amsterdam, 399415.

93. Robison HW, Holsinger JR (2000) First record of the subterranean amphipod crustacean Allocrangonyx hubrichti (Allocrangonyctidae) in Arkansas. Journal of the Arkansas Academy of Science 54: 153.

94. Koenemann S, Holsinger JR (2000) Phylogenetic reconstruction of the subterranean amphipod genus Bactrurus (Crangonyctidae), comparing molecular and morphological data. Polskie Archiwum Hydrobiologii 47: 401-412.

95. Koenemann S, Holsinger JR (2001) Systematics of the North American subterranean amphipod genus Bactrurus (Crangonyctidae). Beaufortia 51: 1-56.

96. Wang D, Holsinger JR (2001) Systematics of the subterranean amphipod genus Stygobromus (Crangonyctidae) in western North America, with emphasis on species of the hubbsi group. Amphipacifica 3: 39-146.

97. Holsinger JR, Ruffo S (2002) Indoweckelia superstes n.gen. n.sp. from the subterranean waters of Socotra Island: the first weckeliid amphipod crustacean (Hadziidae) found in the Indo-West Pacific region. Bollettino del Museo Civico di Storia Naturale di Verona, 26: $27-36$.

98. Zhang J, Holsinger JR (2003) Systematics of the freshwater amphipod genus Crangonyx(Crangonyctidae) in North America. Virginia Museum of Natural History Memoir 6: 1-274.

99. Sawicki T, Holsinger JR, Ortiz M, Perez A (2003) Bahadzia patilarga, a new species of subterranean amphipod crustacean (Hadziidae) from Cuba. Proceedings of the Biological Society of Washington 116: 198-205.

100. Ruffo SJ, Holsinger JR, Sawicki T (2003) Indoweckelia stocki n. sp. from subterranean waters of northern Oman: the second weckeliid amphipod crustacean (Hadziidae) described from the Middle East. Bollettino del Museo Civico di Storia Naturale di Verona 27: 3-11. 
101. Holsinger JR (2004) Crustacea: Amphipoda. In: Gunn J (Ed.) Encyclopedia of Cave and Karst Science. Fitzroy Dearborn, New York, 258-259.

102. Sawicki T, Holsinger JR (2004) Systematics of the subterranean amphipod genus $\mathrm{Ba}$ hadzia (Hadziidae), with description of a new species, redescriptions of B. yagerae, and analysis of phylogeny and biogeography. Journal of Natural History 38: 1397-1414.

103. Morino HH, Kusano H, Holsinger JR (2004) Description and distribution of Crangonyx floridanus (Crustacea: Amphipoda: Crangonyctidae) in Japan, an introduced freshwater amphipod from North America. Contributions from the Biological Laboratory Kyoto Unversity 29: 371-381.

104. Holsinger JR (2005) Vicariance and dispersalist biogeography. In: Culver DC, White WB (Eds) Encyclopedia of Caves. Elsevier Academic Press, Amsterdam, 591-599.

105. Sawicki TR, Holsinger JR, Iliffe TM (2004) Four new species of the subterranean amphipod genus Hadzia (Hadziidae) from caves in the western Pacific, with a re-evaluation of the taxonomic status of the genus. Subterranean Biology 2: 65-90.

106. Sawicki TR, Holsinger JR, Iliffe TM (2005) New species of amphipod crustaceans in the genera Tegano and Melita (Hadzioidea: Melitidae) from subterranean groundwaters in Guam, Palau, and the Philippines. Journal of Crustacean Biology 25: 49-74. https:// doi.org/10.1651/C-2525

107. Sawicki, TR, Holsinger JR (2005) New species and new records of weckeliid amphipod crustaceans (Hadziidae) from subterranean waters in northern Mexico and southern Texas, with descriptions of the new genera Paraholsingerius and Tamaweckelia. Proceedings of the Biological Society of Washington 118: 285-305. https://doi.org/10.2988/0006324X(2005)118[285:NSANRO]2.0.CO;2

108. Iannilli VS, Ruffo S, Holsinger JR (2005) Nubigidiella theresiae n. sp. from Abd al Kuri Island (Crustacea Amphipoda, Bogidiellidae). Bollettino del Museo Civico di Storia Naturale di Verona, Botanica Zoologia 29: 39-45.

109. Sawicki TR, Holsinger JR, Sket B (2005) Redescription of the subterranean amphipod crustacean Flagitopisa philippensis (Hadzioidea: Melitidae), with notes on its unique morphology and clarification of the taxonomic status of Psammogammarus fluviatilis. Raffles Bulletin of Zoology 53: 59-68.

110. Graening, GO, Slay ME, Holsinger JR (2005) Annotated checklist of the Amphipoda of Arkansas with emphasis on groundwater habitats. Proceedings of the Arkansas Academy of Science 59: 80-87.

111. Iannilli V, Holsinger JR, Ruffo S, Vonk R (2006) Two new genera and two new species of subterranean amphipod crustaceans in the family Bogidiellidae from groundwaters in northern Oman, with notes on the geographic distribution of the family. Zootaxa 1208: 37-56.

112. Holsinger JR, Sawicki TR, Graening GO (2006) Bactrurus speleopolis, a new species of subterranean amphipod crustacean (Crangonyctidae) from caves in northern Arkansas. Proceedings of the Biological Society of Washington 119: 15-24. https://doi. org/10.2988/0006-324X(2006)119[15:BSANSO]2.0.CO;2

113. Holsinger JR, Ranga Reddy Y, Messouli M (2006) Bogidiella indica, a new species of subterranean amphipod crustacean (Bogidiellidae) from wells in southeastern India, with remarks on the biogeographic importance of recently discovered bogidiellids on the Indian subcontinent. Subterranean Biology 4: 45-54. 
114. Sidorov D, Holsinger JR (2007) Procrangonyx stygoedincus, a new species of subterranaean amphipod crustacean (Pseudocrangonyctidae) from the far east of Russia, with remarks on biogeographic relationships. Crustaceana 80: 417-430. https://doi. org/10.1163/156854007780440984

115. Graening GO, Holsinger JR, Fenolio DB, Bergey EA, Vaughn CC (2006) Annotated checklist of the Amphipoda of Oklahoma, with emphasis on groundwater habitats. Proceedings of Oklahoma Academy of Sciences 86: 65-74.

116. Messouli M, Holsinger JR, Ranga Reddy Y (2007) Kotumsaridae, a new family of subterranean amphipod crustaceans from India, with description of Kotumsaria, bastarensis, new genus, new species. Zootaxa, 1589: 33-46.

117. Sidorov DA, Holsinger JR (2007) Amurocrangonyx, a new genus of subterranean amphipods (Crangonyctidae) from the Russian Far East, with a redescription redescription of the poorly known Crangonyx arsenjevi and comments on biogeographic relationships. Journal of Crustacean Biology 27: 660-669. https://doi.org/10.1651/S-2817R.1

118. Holsinger JR, Reddell JR (2009) Amphipoda from caves and springs on Fort Hood, Bell and Coryell counties, Texas. Texas Memorial Museum Speleological Monographs 5: 141-146.

119. Holsinger JR, Shafer J, Fong DW, Culver DC (2008) Gammarus cohabitus, a new species of subterranean amphipod crustacean (Gammaridae) from groundwater habitats in central Pennsylvania, USA. Subterranean Biology 6: 31-41.

120. Holsinger JR, Shafer J, Schulte G (2009) Development and application of a database for the subterranean amphipod crustacean genera Stygobromus and Bactrurus. Proceedings of the $15^{\text {th }}$ International Congress of Speleology, Kerrville, Texas 3: 1286-1289.

121. Holsinger JR (2009) Three new species of the subterranean amphipod crustacean genus Stygobromus (Crangonyctidae) from the District of Columbia, Maryland, and Virginia. In: Roble SM, Mitchell JC (Eds) A lifetime of Contributions to Myiapodology and the Natural History of Virginia: A Festschrift in Honor of Richard L. Hoffman's $80^{\text {th }}$ Birthday. Virginia Museum of Natural History Special Publication No. 16, Martinsville, 261-276.

122. Culver DC, Holsinger JR, Christman MC, Pipan T (2010) Morphological differences among eyeless amphipods in the genus Stygobromus dwelling in different subterranean habitats. Journal of Crustacean Biology 30: 68-74. https://doi. org/10.1651/09-3156.1

123. Sidorov DA, Holsinger JR, Takhteev VV (2010) Two new species of the subterranean amphipod genus Stygobromus (Amphipoda: Crangonyctidae) from Siberia, with new data on Stygobromus pusillus (Martynov) and remarks on morphology and biogeographic relationships. Zootaxa 2478: 41-58.

124. Niemiller ML, Osbourn MS, Fenolio DB, Pauley TK, Miller BT, Holsinger JR (2010) Conservation status and habitat use of the West Virginia Spring Salamander (Gyrinophilus subterraneus) and spring salamander (G. porphyriticus) in General Davis Cave, Greenbrier Co., West Virginia. Herpetological Conservation and Biology 5: 32-43.

125. Taylor SJ, Holsinger JR (2011) A new species of the subterranean amphipod crustacean genus Stygobromus (Crangonyctidae) from a cave in Nevada, USA. Subterranean Biology 8: 39-47. https://doi.org/10.3897/subtbiol.8.1230 
126. Kornobis ES, Palsson S, Sidorov DA, Holsinger JR, Kristjansson BK (2011) Molecular taxonomy and phylogenetic affinities of two groundwater amphipods, Crangonyx islandicus and Crymostygius thingvallensis, endemic to Iceland. Molecular Phylogenetics and Evolution 58: 527-539. https://doi.org/10.1016/j.ympev.2010.12.010

127. Holsinger JR, Ansell LM, Shafer J (2011) Four new species of the subterranean amphipod genus Stygobromus (Amphipoda: Crangonyctidae) from shallow groundwater habitats on the Coastal Plain and eastern margin of the Piedmont in Maryland and Virginia, USA. Zootaxa 2972: 1-21.

128. Culver DC, Holsinger JR, Feller DJ (2012) The fauna of seepage springs and other shallow subterranean habitats in the mid-Atlantic Piedmont and Coastal Plain. Northeastern Naturalist Monograph 19: 1-42. https://doi.org/10.1656/045.019.m901

129. Holsinger JR (2012) Vicariance and dispersalist biogeography. In: White WB, Culver DC (Eds) Encyclopedia of Caves. Academic Press, Amsterdam, 849-858. https://doi. org/10.1016/B978-0-12-383832-2.00123-7

130. Sidorov A, Pankov N, Holsinger (2011). Distribution and ecology of the subterranean amphipod Crangonyx chiebnikovi Borutzky 1928 (Crustacea: Crangonyctidae), with lectotype designation and comments on morphology of the lateral cephalic lobe. Arthropoda Selecta 21: 149-160.

131. Graening, GO, Christopher D, Holsinger JR, Barr C, Bottorff R (2012) Checklist of inland aquatic Amphipoda (Crustacea: Malacostraca) of California. Zootaxa 3544: $1-27$.

132. Holsinger JR (2013) A brief history of biospeleology in Virginia. Banisteria 42: 3-8.

133. Holsinger JR, Culver DC, Hubbard Jr DA, Orndorff WD, Hobson CS (2013) The invertebrate cave fauna of Virginia. Banisteria 42: 9-56.

134. Holsinger JR, Ansell L (2014) A new species of the subterranean amphipod genus Stygobromus (Amphipoda: Crangonyctidae) from two caves and a seep in western Maryland, USA with additional records of undescribed species from groundwater habitats in central Maryland. Zootaxa 3768: 386-394. https://doi.org/10.11646/zootaxa.3768.3.6

135. Holsinger JR, Sawicki TR (2016) A new species of the subterranean genus Stygobromus (Amphipoda: Crangonyctidae) from a cave spring in northern Florida, USA. Zootaxa 4067: 88-94. https://doi.org/10.11646/zootaxa.4067.1.7

136. Sawicki TR, Holsinger JR, Lazo-Wasem, DA, Long RA (2017) A new species of subterranean amphipod (Amphipoda: Gammaridae: Crangonyctidae) from Florida, with a genetic analysis of associated microbial mats. Journal of Crustacean Biology 37: 285-295. https://doi.org/10.1093/jcbiol/rux031 